\title{
Spanish Cities of the Golden Age
}







\title{
Spanish Cities of the Golden Age
}

\section{The Views of Anton van den Wyngaerde}

\author{
Edited by Richard L. Kagan
}


University of Californa Press

Berkeley and Los Angeles, Californu

University of California Press, Ltd.

London, England

\section{O 1989 by}

The Regents of the University of California

The publisher acknowledges

with gratitude the generous support

given this book from the

Art Book Fund

of the Associates of the

University of California Press,

which is supported by a major gift

from The Ahmanson Foundation.

Publication of thus book has been supported by a grant from the National Endowment for the Humanties, an independent federa agency.

The publssher also gratefully acknowledges the assistance of the Spanish Ministry of Culture and the Program for Cultural

Cooperation between Span's Ministry of Culture and United States Universibes for their generous support.

Chapter III, "The Spanush Views of Anton van den Wyngaerde" by Egbert Haverkamp-Begemann, appeared in a slightly different version in Master Drawings 7, no. 4 (1969): 375 99. Grateful acknowledgment is made to Master Drawings Assocation, Inc , for permission to reprint the article

Sources of the Illustrations: Archivo General de Simancas, Archivo Oronoz (Madnd), A. C. Cooper Ltd. (London), Kungl. Biblioteket (Stockholm), Lichtbuldwerkstätte Alpenland (Vienna), Museo del Prado (Madnd), Patnmonio Nacoonal (Madnd), photographtc services of the Österrechusche Nationalbiblothek (Vienna), photographic services of the Victora and Albert Museum (London).

Library of Congress Cataloging-in-Publication Data

Spanush aties of the golden age' the views of Anton van den Wyngaerde / edated by Ruchard L. Kagan.

p. $\mathrm{cm}$

Bibliography $\mathrm{p}$

Includes index.

ISBN 0-520-05610-8 (all. paper)

1 Wyngaerde, Anton van den, d. 1571-Catalogs. 2. Cities and towns in art-Catalogs 3. Cities and towns-Span-History16th century-Pictornal works-Catalogs 4 Philip II, King of Spaun, 1527-1598-Art patronage I. Kagan, Ruchard L., 1943NC266. W96A4 1989

$7419493-$ dc19

$88-10664$

Printed in Spain

$\begin{array}{lllllllll}9 & 8 & 7 & 6 & 5 & 4 & 3 & 2 & 1\end{array}$ 